\title{
Refugee Exodus from Somalia: Revisiting the Causes
}

\author{
Hassan A. Mohamed
}

\begin{abstract}
Résumé
Cet article se propose d'examiner les causes du conflit Somalien qui a provoqué l'exode de plus de deux millions de réfugiés. Par une approche historique du développement de la tragédie, l'auteur offre une perspective plus complexe et très différente de celle offerte par les médias qui se cantonnent dans des discussions simplistes et superficielles des symptômes actuels. Pour Hassan Mohammed, les causes de la crise Somalienne sont liées à un processus de désintégration de la société civile et de ses valeurs sociales, culturelles et politiques, une désintégration qui résulte de quatreévènements historiques: le découpage de la nation et du territoire Somalien en plusieurs entités; l'impact de la guerre froide; l'imposition de systèmes politique, culturel et éducatif étrangers à la culture Somalienne; et enfin, la manipulation et l'exploitation des divisions claniques par l'élite politique afin de demeurer au pouvoir.
\end{abstract}

\section{Introduction}

The most recent and probably the largest refugee exodus in the history of the Horn of Africa started in Somalia in 1988. By the end of 1992 , the world had witnessed the ugly consequences of four years of civil war and famine that had devastated Somalia and led to the disintegration of the state and civil society. The destructive forces of war and famine have claimed the lives of approximately 350,000 Somalis and sent more than one million refugees to every corner of the globe. Most of the refugees fled to neighbouring countries. According to sources such as U.S. Committee for Refugees (1993) and UNHCR (1993) there were about 400,000 Somali refugees in Ethiopia in 1992, another 320,000 in Kenya and approximately 85,000 hosted by tiny Djibouti. Another 250,000 refugees were dispersed in Asia, Europe and North America. Besides, about two million people were internally displaced (see Tables 1-4).

This article discusses the causes of the Somali disaster from a different perspective than the standard main-

\footnotetext{
Hassan A. Mohamed is a doctoral candidate at the Center for International Education, University of Massachusetts at Amherst, and a research associate at CRS, York University.
}

stream explanations. The severity of the crisis in Somalia was largely unknown to the outside world prior to the televised images of starving multitudes and marauding armed youngsters which attracted the world's attention-eventually leading to the now famous "Operation Restore Hope." But the impressions portrayed gave neither an accurate picture nor adequately explained the genesis of the crisis. In most cases, the causes of the current chaos and crises in Somalia have been attributed to internal factors, such as "a senseless tribal war over state-control." This became the standard premise for most of the popular and academic writings on the crisis in Somalia.

The fixation on the immediate social crisis-such as lawlessness, anarchy and starvation-can be both misleading and unjust. It is misleading because the emphasis is on the symptoms and not on the causes of the situation. This approach not only leads to inadequate understanding of the problems but is also unjust when the diagnosis primarily focuses on the single dimension of internal factors, while ignoring external and historical aspects. Such a single-sided approach tended "to blame the victims for their misery and agony" (Keynan 1992) and resulted in the portrayal of Somalis as "either gun-crazy looters or as hapless victims" that needed to be rescued from themselves (Rakia 1992).

It is unfortunate that the discourse on the crisis in Somalia has so far ignored the complex historical development of the tragedy. Abdi Samatar $(1992,626)$ aptly described the problem:

One of the casualties of the gruesome nightmare that is gripping Somalia has been the capacity to think historically and systematically about the nature of the malady, and to find practical ways of controlling the present in order to build a more sustainable future.

The failure of "Operation Restore Hope" is an apt illustration of this point; the good intentions of the operation made many innocent Somalis victims rather than beneficiaries of the supposedly humanitarian intervention.

To understand fully the causes of the crisis, it is necessary to go beyond the traditional scholarship which tends to reduce the causes to a single factor, namely, Somali segmentary clanism (Abdi Samatar 1992 and Keynan 1992). The causes behind the crisis are the result of an interplay of political, economic, sociocultural and ecological factors that have been in the making for a long time (Wisner 1992; Keynan 1992 and Abdi Samatar 1992). The correlations of these can be understood from a historical perspective that views the disintegration of indigenous social systems and civil society as the consequences of:

1. the impact of the colonial legacy especially the partition of the Somali nation and territories;

2. the legacy of the Cold War;

3. the imposition of alien centralized structures, systems of governance, culture and education which contributed to the disintegration of the indigenous political, economic and sociocultural modes of life and structures that were compatible 
with the harsh and precarious environment of the Horn of Africa; and finally

4. the failure of the mentally colonized ruling elite to develop viable alternatives to western values and systems of governance rather than resorting to the manipulation and exploitation of the segmentary nature of the Somali social system in order to stay in power.

\section{The Partition of the Somali Nation:}

\section{A Colonial Legacy}

A major causal factor in the current crisis is the impact of the colonial partition of Somali nation into five separate parts: British Somaliland in the north; North Frontier District (NFD, which Britain later ceded to Kenya); Italian Somaliland in the south; French Somaliland (now Djibouti); and a large region known as Ogaden which all three European powers relinquished portions of to Emperor Menelik of Ethiopia as a reward for his collaboration (Lewis 1988; Harbeson 1991; Zolberg 1992 and Sheikh-Abdi 1993). Only two parts of the Somali nationthe former British Somaliland and former Italian Somaliland-out of five gained independence and united, on July 1, 1960 to form the present Somali Democratic Republic. For Somalis, one of the most devastating results of the colonial partition was that it "frustrated Somali national aspirations and fractured the basis for statehood laid

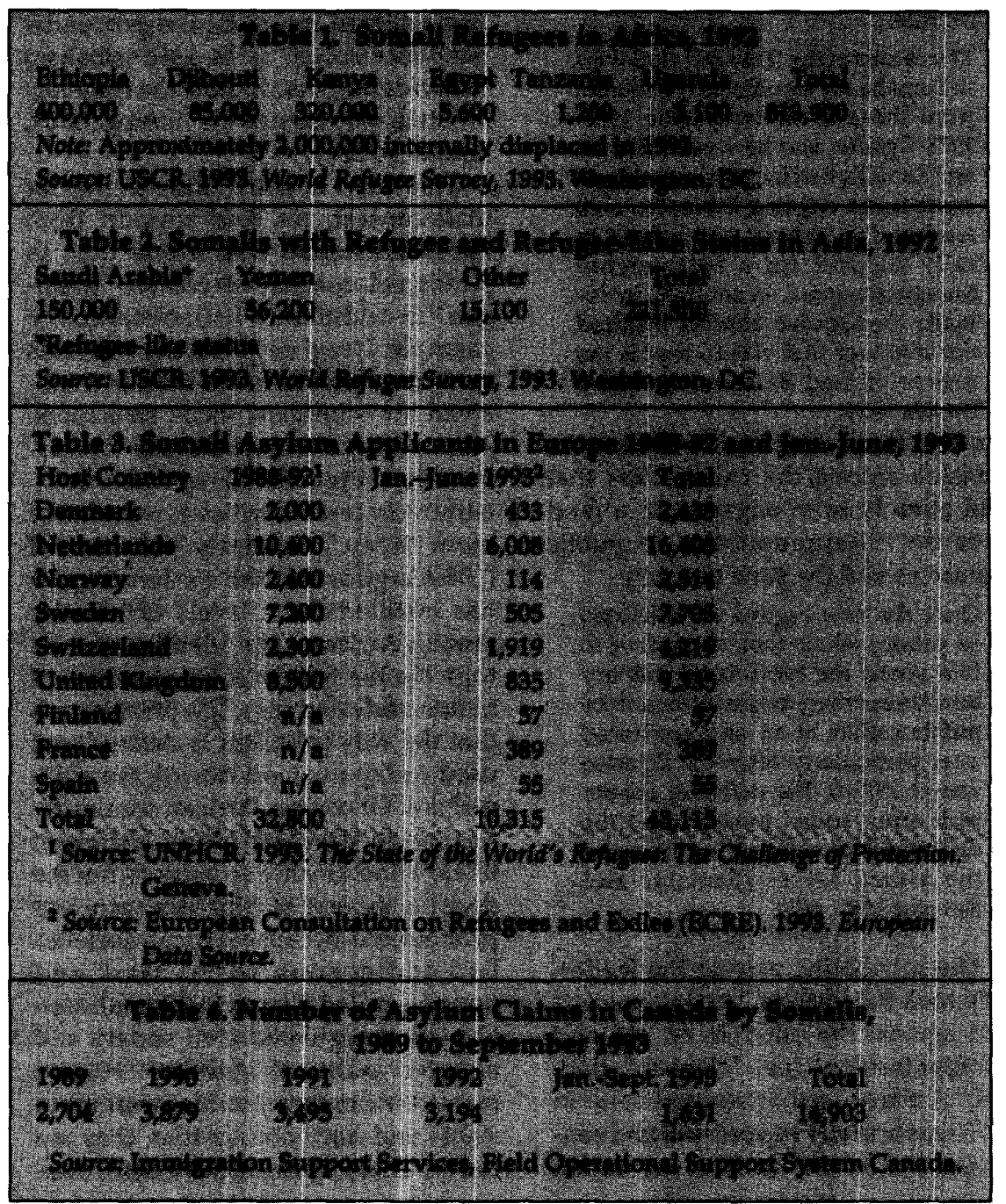

by stable colonial rule elsewhere [in Africal" (Harbeson 1991). Consequently, this legacy gave birth to strong sentiments of Pan-Somalism, whose pursuit helped precipitate sporadic wars between Somalia and Ethiopia. For example, the wars of 1960 , 1963-64 and 1976-78 directly contributed to several refugee populations. Before we discuss Pan-Somalism let us first look at the role of the superpowers during the Cold War era in the Horn of Africa.

\section{The Role of the Superpowers}

The proximity of the Horn of Africa to the Suez Canal and the oil rich Middle East have made it attractive to foreign involvement in its affairs. The United States and the former Soviet Union, driven by geopolitical and ideological motives, turned the Horn of Africa into one of the most bitterly contested battlefields of the Cold War. Since the early 1960s, the superpowers-partly in response to the demands of their local clients-dumped massive amounts of deadly weapons into the region.

Somalia and Ethiopia are among the poorest countries in the world, yet during the 1970s and 1980s their military rulers diverted tremendous amounts of national resources to build and sustain huge standing armies. One Somali writer, Keynan (1993) estimated that Somalia spent between 60 and 80 percent of its annual budget on defense. He put the annual public expenditure per soldier at \$US 2,065; compared to, say, the salary of \$US 100 to a senior lecturer at the Somali $\mathrm{Na}$ tional University. The cost of soldiers weapons to the local people-delivered in the form of loans and aidexceeded \$US 12 billion. For example, at the height of Ogaden war in "just five months, between November 1977 and March 1978, the Soviet Union dumped \$US 2 billion worth of sophisticated weaponry in the Horn (Keynan 1992, 6-7)." Today, the deadly arms in the hands of the Somalis that confront the UN multilateral military mission are the legacy of the Cold War (Zolberg 1992). There is no need to elaborate the

Refuge, Vol. 14, No. 1 (April 1994) 
role these arms have played in Somalia's ongoing destruction and refugee exodus.

\section{Pan-Somalism: The Faded Dream}

The post-colonial regimes of Somalia spent considerable amounts of energy and resources toward unification of the dismembered Somali nation. Pursuing this dream led to constant hostilities and open warfare between Somalia and the neighbouring countries of Ethiopia and Kenya during the 1960s. A decade later, sensing the decline of the legitimacy of their military rule, Siad Barre (Somalia's former dictator) and his colleagues played their final card-Pan-Somalism, a matter heavy in every Somali's heart.

In 1975, Somalia supported the dominant Western Somali Liberation Movement (WSLF) in Ogaden (under Ethiopian rule) in an attempt to realize the dream of Somali unification. On July 23, 1977 the Somali army entered Ogaden in support of WSLF. It quickly captured more than 95 percent of the Somali inhabited lands and launched assaults on the outskirts of Harar/and Dira-Dawa.

The balance of power changed when the former military regime in Ethiopia broke off relations with the United States. At the same time, Somalia expelled the Soviets. Viewing the Horn of Africa as a strategic area, the superpowers switched horses. The Soviet Union embarked on a massive airlift, which the world had not experienced since the World War II, to support the Ethiopian side and to save Mengistu's regime. Siad Barre was unable either to persuade Russia to be neutral or to secure western help. Consequently, Somalia lost the war to the forces of Ethiopia, equipped with $\mathrm{Cu}$ ban, East German and Soviet expertise and technology.

\section{The Aftermath of Ogaden War}

The Somali rulers had disastrously miscalculated the whole endeavour and the Somali people paid a costly price. First, there was the unprecedented flight of 1.5 million refugees from the vengeful re-imposition of
Ethiopian rule in Ogaden. Second, the defeat had a negative psychological impact on the morale and self-esteem of the population and set the stage for the political disintegration of Somali unity. Once the last hope for PanSomalism had vanished, all of the resources, energy and sentiments that had been directed toward the external enemies became a double edged sword that was now turned inward. Third, people could no longer endure the political, economic and social hardships, and openly challenged the leadership as a result. Thus, the pursuit of Pan-Somalism had directly contributed to the present destruction. Harbeson (1991, 223), comparing the consequences of Ogaden war for the rulers of Ethiopia and Somalia, also contends:

The causes of the [current] civil wars in Somalia are significantly different from those in Ethiopia. The 1977. 1978 Ogaden war between Ethiopia and Somalia had failed to extend and escalate the ongoing Ethiopian civil wars and in general had helped to rally support for a beleaguered Mengistu regime. In contrast, in Somalia the Ogaden conflict inspired the civil war that was to topple the regime of Siad Barre more than a decade later.

Finally, the defeat had widened the division among the ruling class that had already been engaged in a feud over the misappropriation of public resources and the state treasury:

Once the new regime consolidated its power, which took about four to five years, the hard-fisted military bureaucracy began openly to raid the public coffers at an unprecedented rate, particularly after the Ogaden war of 1977-8. The defeat of the Somali army added more fuel to the disintegration of the ruling junta and the armed forces (Samatar and Samatar 1987, 683).

The squabbling among the leadership took the form of "pitting one faction against the other in an old and familiar fashion" (i.e., "clanism"; ibid, 684). A clan-based attempted coup in 1978 was brutally suppressed and consequently the resources of the nation were diverted to the diverse warring factions among the elite.

\section{Tribalism in African Social Systems}

Son, the tribalism business is the work of the urban people. They cook it there and then serve it to us. (Issa, a peasant in Jowhar, spring 1990 ; Quoted by Abdi Samatar 1992, 625).

One of the major contentions of this paper is that the majority of Somalis do not view tribalism as the cause of their problems but rather as the creation of the ruling elites. In the past, it had been the colonial administrations that used the "centrifugal tendencies" of indigenous social structures as a divide and rule strategy to consolidate their power. In the pursuit of their economic and political interests, the post-independence ruling elites used tribalism to divide and manipulate the clan-segmented, but otherwise homogenous, Somali society.

This view is not unique to the Somali context; we find support from African scholars who argue that, in Africa, colonialism has created "tribalism" in addition to nation-states. For example, Osaghae $(1991,28)$ contends that "modern" forms of tribe and tribalism are emergent social structures. He cites Raymond Apthorpoe who argues that "the colonial regimes administratively created tribes as we think of them today." Similarly, Ali Mazrui (1980) argues that the western impact has instilled three levels of identity among Africans: the identity of tribe tops the list followed by identities of nation-state and race. The point here is that the way tribalism is defined and used today evolved during the colonial era. Of course, African communities were divided along different lineage and kinship structures, but the divisive aspects of tribalism were less pronounced because African societies had indigenous social laws and norms-called Xeer in the Somali context-that regulated civil society and ensured political stability. Hence, many African communities were more stable and harmonious than they are today. These systems have been mar- 
ginalized as result of colonialism and western influence.

\section{The Indigenous Somali Social System: Kinship and Xeer}

For centuries the "pillar of Somali social structure" was the communal system based on family and clan relationships and interactions (Abdi Samatar 1992, 629). Each basic family unit or household stood as an "autonomous unit" in its economic production, yet the neighbouring groups had guaranteed their own physical and social security through formal contracts (Xeer) of alliances among men who calculated their loyalties to one another in terms of kinship. Kinship, a misunderstood concept in the case of Somalia, is more complex than simple biological relationship. A Somali scholar has recently described the full meaning of kinship in the pre-colonial Somali social order as follows:

The ideology of kinship had two central elements: Blood-ties and Xeer.

The first was essentially a product of genealogical connections buttressed by a patrilineal system harking back to real or invented common origin/ ancestor; the latter was the embodiment of common wisdom and the locus of inter/intra generational and, in its most general depiction, a PanSomali code of conduct. The combined meaning of these elements constituted the milieu in which both the private and the public were defined. This, then, was the basis of kinship-an ideology commensurate with reciprocal production relations (Abdi Samatar 1992, 630).

Historically, in the absence of centralized and "institutionalized state structures," the Xeer was a socially constructed system of norms and values established to ensure the security, social justice and harmony of Somali pastoral communities. The Xeer system was latter modified and reinforced by Islamic values. The role of Xeer was to codify the political obligations of interclan, as well as intra-clan, lineage mates and their followers who collaborated socially and economically to share certain labour tasks, to defend or extend grazing areas, and to redistrib- ute basic productive or subsistence resources to individuals in need. In this context, the Xeer kinship system served both as a cohesive and a divisive factor, depending on the dictates of the prevailing social, political and economic relations of the society-i.e., whether they were antagonistic or cooperative. The nature of these relationships were largely moderated by the Xeer between the different groups. The excesses of segmentary clanism were tamed and constrained by the obligatory values of Xeer just as western individualistic society is regulated by law and order.

In pre-colonial Somalia this system was somewhat stable, Abdi Samatar $(1992,631)$ described the resilience and viability of the pre-colonial Somali Xeer system as follows:

What gave the Xeer staying power in the absence of centralised coercive machinery was the voluntarism associated with the absolute necessity of relying and living on one's labour/livestock rather than exploiting others. Such an ethic-in conjunction with Islam-prevented and restrained centrifugal tendencies in the lineage system, thereby inhibiting terrible men from plunging the community into a nightmare.

With the advent of the western-style centralized state, the Xeer system was continuously undermined by superseding state laws and rules. Modern Somali (and African) state rulers and elites may no longer be guided by values based on Xeer as these were replaced by foreign social values and systems of governance.

\section{The Post-Colonial Centralized State}

In most Third World countries and particularly Africa, the post-colonial ruling class inherited the colonial structures and its culture of state management. This fact created a dependency relationship with former colonial powers which constituted not only economic and political but also cultural and intellectual aspects. The depth of such dependence was such that the "colonial regime was to relinquish visible power but not to lose de- cisive influence" as Abdi Samatar-and Ahmed Samatar $(1987,680)$ put it. Thus, the post-colonial leaders have used Eurocentric colonial models in all aspects of governance. Michael Crowder also attests:

The colonial experience has affected the way Africa has developed over the past twenty-five years... there are many parallels to be found between the colonial state and the independent state than are conceded (Samatar and Samatar 1987, 680).

In the case of Somalia, the adoption of British style parliamentary politics exemplifies the imprint of colonial heritage on its disciples who came into power, not to mention that the constitution they were following was drafted by foreign experts:

The Somali Independence Constitution of 1960 was written by Italian and American experts, one of whom reputedly boasted of drafting the constitution in a Rome hotel over a bottle of whisky (Adam 1992, 22).

This fact illustrates the colonized mentality of the Somali elites which led to their failure to develop the country even according to western systems-for they were as divorced from the reality of the country they were leading as was their foreign drafted constitution.

\section{Clanism and Elite Manipulation in Somalia}

Some scholars perceive the Somali indigenous social system as egalitarian, labelling it "pastoral democracy" (Lewis 1961; Touval 1963; Laitin and Samatar 1987). Furthermore, they have suggested that a multiparty system would be consistent with the pastoral values of the Somalis. Hence, the constitution of the new Somali State, up until 1969, guaranteed the freedom to organize and compete for political office through a multiparty westernstyle political system. But what was inconsistent with the pastoral ethos of the Somali people was the emphasis the new constitution placed on the individual entity in contrast to groupclan-entity. There is a difference between the western notion of democ- 
racy that is based on values of individualistic society as compared to the Somali pastoral democracy that is based on communal social system and values-an aspect that has been overlooked.

The failure to appreciate such differences led to the derailment of the infant parliamentary democracy and the emergence of clan-based political rivalry at the national level. The segmentary nature of Somali society became the Achilles' heel that power hungry elites exploited. National resources were distributed through clans rather than through an impartial merit system. Individuals were promoted on the basis of their clan ties rather than on their individual merit and proven leadership qualities. This practice, which was neither western nor indigenous but somewhat akin to that of colonial administration, incited factionalism and aggravated the "anarchic tendencies already present in the society" (Laitin and Samatar 1987, 76). The result was chaos and the derailment of the democratic process.

There was a contradiction between the ideal and the practical, a lack of integrity on the part of the leaders and a confusion in the Somali psyche. A double standard of moral norms developed and was internalized to the extent that the Somali individual, on the one hand, publicly abhors clanism, and on the other, privately relies on it to attain personal ends. Somali psychiatrist, Hussein Bulhan (1992, 13) describes this phenomenon as follows:

Few things reveal the social neurosis of the westernized Somali as the incongruence of what he declares in public versus what he acts upon in the privacy of his clan.

Siad Barre, an ex-officer of the colonial army and a shrewd player of Somali clan politics, exploited this phenomena to prolong his rule for more than two decades. With the help of state treasury he courted the loyalties of clan leaders and played them off against each other-to the point of supplying funds and ammunition to opposing groups. Those who opposed Barre played the same game as he did. Sub- sequent challenges to his leadership were invariably organizationally clanbased. Trust rather than ideas or ideology became the determining factor in political alliances.

Eventually, in late 1990, Barre's notso-secret practice of divide and rule broke down. At home he simply ran out of clans: the Ogadens; the largest and vital Hawiye; and even the quiet and peaceful Rahanwayn deserted him. Finally, the USC (mainly constituted of Hawiye clans) with the help of others overran Barre's palace in early January 1991. But instead of sharing the leadership, the factional leaders fought over it, fuelling a new inter-clan civil war that killed more than 350,000 Somalis and scattered two million refugees around the globe.

\section{Conclusion}

There is no denial that it is Somalis who are killing each other in clanbased conflict. However, to focus solely on clanism is overly simplistic and gives a misleading explanation of the causes of the present crisis. The real causes of civil conflict in Somalia lie less with the nature of clan segmentation and more with the impact of the partition of the Somali nation; the manipulation by the ruling elites of the Somali segmentary social system; the marginalization of the indigenous social system (Xeer); and the inadequacy of the mediating role of the rulers and the state mechanisms that replaced it. It is the combination of the above factors that led to the destruction of the country and the fabric of the Somali nation.

\section{References}

Adam, Hussein M. 1992. "Somalia: militarism, warlordism or democracy?" Review of African Political Economy 54:11-26.

Bulhan, Hussein. 1992. "The legacy of despotism." Paper presented in a symposium, Somalia: Human disaster and world politics, October 15-16, 1992, Cornell University: Institute for African Development.

Harbeson, John. 1991. "The Horn Of Africa: From chaos, political renewal?" Current History (May):221-224.
Keynan, Hassan. 1992. "The making of the Somali tragedy and how it can be tackled." Unpublished paper.

Laitin, D.D. and S.S. Samatar. 1987. Somalia: Nation in search of a state. Boulder, Colorado: Westview Press.

Lewis, I.M. 1979. "Kim Il-Sung in Somalia: The end of tribalism?" In Politics in leadership: $A$ comparative perspective, edited by W.A. Shack and S.P. Cohen. Oxford: Clarendon Press.

-1969. "Nationalism and particularism in Somalia." In Tradition and transition in East Africa: Studies of the tribal element in modern era, edited by P.H. Gulliver. Routledge \& Kegan Paul.

- 1961. A pastoral democracy: A study of pastoralism and politics among the Northern Somali of the Horn Of Africa. London: Oxford University Press.

-1961. "Force and fission in Northern Somali lineage structure." American Anthropology 631:95-112.

Mazrui, Ali. 1980. The African condition. London: Cambridge University Press.

Osaghae, Eghosa. 1991. "Colonialism and African political thought." UFAHAMU 19(2\&ะ3):22-37.

Omaar, Rakia. 1992. "Human rights: Victims of national disintegration." Paper presented in a symposium, Somalia: Human disaster and world politics, October 15-16, 1992, Cornell University: Institute for African Development.

Samatar, Abdi and Ahmed Samatar. 1987. "The material roots of the suspended African state: Arguments from Somalia." The Journal of Modern African Studies 25(4):669-690.

Samatar, Abdi. 1992. "Social classes and economic restructuring in pastoral Africa: Somali notes." African Studies Review 251:101-27.

Samatar, Ahmed. 1988. Socialist Somalia: Rhetoric and reality. London: Zed Books.

_. 1987. "Somalia impasse: state power and dissent politics." Third World Quarterly 9 (3):871-90.

Sheik-Abdi, Abdi. 1993. Divine madness: Mohammed Abudulle Hassan 1856-1920. London: Zed Books.

Touval, Saadia. 1963. Somali nationalism: International politics and the drive for unity in the Horn of Africa. Cambridge, Mass.: Harvard University Press.

Wisner, Ben. 1992. "The political ecology of famine in Somalia." Unpublished paper.

Zolberg, Aristide. 1992. "The spectre of anarchy." Dissent (Summer):303-11. 